\title{
OPEN \\ ACCESS \\ News Framing of the Extraordinary Congress Partai Demokrat at Kompas.com
}

\author{
Pembingkaian Berita Kongres Luar Biasa Partai \\ Demokrat pada Kompas.com
}

\section{Selvi Triwahyuni}

\section{INSTITUTION}

Universitas Budi Luhur

Indonesia

\section{PHONE}

EMAIL

selvitriwahyuni8@gmail.com

\section{DOI}

https://www.doi.org/

10.37010/prop.v2i1.579

\section{PAPER PAGE}

89-98

PROPAGANDA is a

Journal of Communication Studies which is publish twice a year on January and July. PROPAGANDA is a scientific publication media in the form of conceptual paper and field research related to communication studies. It is hoped that PROPAGANDA can become a media for academics and researchers to publish their scientific work and become a reference source for the development of science and knowledge.

\begin{abstract}
Perebutan kekuasaan sebenarnya bukan permasalahan yang baru dalam dunia politik Indonesia. Menjadi ketua umum partai tidak hanya sebagai penentu berbagai keputusan kebijakan partai, tetapi memiliki kesempatan kuat untuk dicalonkan dalam pemilihan presiden ataupun masuk dalam struktur penting dalam lembaga pemerintahan Indonesia. Jadi termasuk bukan hal yang baru lagi jika posisi ketua umum partai itu menjadikan posisi yang selalu diperebutkan oleh elite partai. Berkaitan dengan berita, media pasti mempunyai caranya sendiri dalam membingkai suatu berita. Penelitian ini bertujuan untuk mengetahui bagaimana Kompas.com membingkai berita Kongres Luar Biasa Partai Demokrat periode 5-6 Maret 2021. Penelitian ini menggunakan paradigma konstruktivisme dengan pendekatan kualitatif. Metode penelitian yang digunakan dalam penelitian ini adalah analisis framing Robert N. Entman, yang di mana memiliki dua dimensi besar yaitu seleksi isu dan penonjolan aspek serta memiliki empat elemen framing yaitu define problems, diagnose causes, make moral judgement, dan treatment recommendation. Hasil penelitian menunjukkan bahwa Kompas.com menempatkan berita Kongres Luar Biasa Partai Demokrat ini ke dalam masalah politik. Hal tersebut dapat dilihat dari pemilihan narasumber dan pernyataan yang dilontarkan, serta penonjolan aspek yang ditunjukkan, Kompas.com lebih menampilkan sisi kontra Moeldoko selaku Kepala Staf Kepresidenan, kemudian ada Marzuki Alie yang merupakan Sekretaris Jenderal Partai Demokrat dan Darmizal selaku Wakil Ketua Komisi Pengawas Partai Demokrat. Moeldoko ditempatkan sebagai aktor penyebab masalah yang telah menimbulkan kehebohan publik.
\end{abstract}

The struggle for power is actually not a new problem in Indonesian politics. Being the general chairman of the party is not only a determinant of various party policy decisions, but has a strong opportunity to be nominated in the presidential election or enter into important structures in Indonesian government institutions. So, it is not something new anymore if the position of the general chairman of the party is a position that is always contested by the party elite. Regarding news, the media must have their own way of framing news. This study aims to find out how Kompas.com frames the news of the Extraordinary Democratic Party Congress for the period 5-6 March 2021. This study uses a constructivist paradigm with a qualitative approach. The research method used in this study is Robert N. Entman's framing analysis, which has two major dimensions, namely selection of issues and highlighting aspects and has four framing elements, namely define problems, diagnose causes, make moral judgments, and treatment recommendations. The results show that Kompas.com places the news of the Extraordinary Democratic Party Congress into political issues. This can be seen from the selection of sources and statements made, as well as the highlighting of the aspects shown, Kompas.com shows the contra side of Moeldoko as the Presidential Chief of Staff, then there is Marzuki Alie who is the Secretary General of the Democratic Party and Darmizal as the Deputy Chair of the Democratic Party Supervisory Commission. Moeldoko was placed as an actor causing problems that have caused a public uproar.

\section{KEYWORD}

berita, framing, media online

news, framing, online media 


\section{PROPAGANDA}

\section{PENDAHULUAN}

Agus Harimurti Yudhoyono (AHY) selaku Ketua umum Partai Demokrat kini menjadi perbincangan yang hangat di dunia politik Indonesia. Awal bulan Februari 2021 beredar kabar berita politik Indonesia mengenai isu kudeta, Agus Harimurti Yudhoyono mengeluarkan pernyataan bahwa terdapat pihak-pihak yang hendak melakukan kudeta terhadap Partai Demokrat untuk kepentingan pemilihan presiden di tahun 2024.

Tidak berlangsung lama dari pernyataan AHY, pada tanggal 5 Maret 2021 anggota partai mengadakan Kongres Luar Biasa (KLB) di gelar di The Hill Hotel and Resort Sibolangit, Deli Serdang, Sumatra Utara. Dipilihnya Kepala Kantor Staf Kepresidenan yaitu Moeldoko sebagai ketua umum Partai Demokrat dilihat dari hasil Kongres Luar Biasa kubu kohtra AHY yang dilakukan melalui pemilihan suara dari para peserta yang hadir. Selain Moeldoko yang diajukan untuk menjabat sebagai ketua umum Partai Demokrat yaitu Marzukie Alie, tetapi Moeldoko yang unggul dalam pemilihan tersebut. Kongres Luar Biasa di dalangi seorang mantan kader Demokrat yang sebelumnya sudah diberhentikan secara tidak hormat.

AHY menyatakan Kongres Luar Biasa Partai Demokrat tersebut tidak memenuhi ketentuan yang harus dilakukan sebelum diadakannya Kongres Luar Biasa sebagaimana termuat pada anggaran dasar dan anggaran rumah tangga (AD/ART). Berdasarkan anggaran dasar dan anggaran rumah tangga, Kongres Luar Biasa dapat dilakukan jika disepakati, didukung, dan dihadiri oleh dua pertiga dari jumlah Dewan Pimpinan Daerah (DPD) dan setengah dari jumlah Dewan Pimpinan Cabang (DPC). Kecuali penyelenggara Kongres Luar Biasa juga harus melalui persetujuan ketua Majelis Tertinggi Partai Demokrat yang saat ini di ketua oleh Susilo Bambang Yudhoyono. (Ramadhan, 2021)

Perebutan kekuasaan sebenarnya bukan permasalahan yang baru dalam dunia politik Indonesia. Menjadi ketua umum partai tidak hanya menentukan berbagai keputusan kebijakan partai, akan tetapi memiliki kesempatan yang cukup kuat untuk dicalonkan pada pemilihan presiden ataupun masuk struktur penting dalam lembaga pemerintahan Indonesia. Jadi termasuk bukan hal yang baru lagi jika elite partai bersaing untuk mendapatkan jabatan ketua umum partai.

AHY sebelumnya berpendapat bahwa terdapat sejumlah pihak yang hendak menggantinya dari kursi ketua umum dengan melakukan adanya KLB. Para mantan pengurus Partai Demokrat yang diduga yakni Marzuki Alie, Darmizal, Muhammad Nazaruddin, serta politisi aktif Demokrat Jhoni Alen Marbun. Kemudian AHY menyatakan bahwa terdapat pejabat pada lingkungan Istana Kepresidenan yang terlibat upaya pelengserannya dengan menggulirkan isu KLB. Pejabat yang dimaksud ialah Kepala Kantor Staf Presiden Moeldoko. Moeldoko membantah tudingan tersebut dan mengaku tidak memiliki hak untuk mengambil alih kepemimpinan Partai Demokrat sebab bukan bagian dari internal partai.

Perebutan kekuasaan tersebut mengakibatkan pemberhentian secara tidak hormat atau pemecatan pada tujuh orang kader partai demokrat yaitu Darmizal, Yus Sudarso, Tri Yulianto, Jhoni Allen Marbun, Marzuki Alie, Syofwatillah Mohzaib, dan Ahmad Yahya, diberhentikan karena dianggap terlibat dan membantu gerakan kudeta. Dewan kehormatan menyatakan, bahwa mereka mendiskreditkan, mengadu domba, mengancam, menghasut, melakukan bujuk rayu dengan memberikan imbalan uang dan jabatan kepada kader pengurus partai. Kemudian, menyebarluaskan kabar bohong dan fitnah dengan menyampaikan pada kader dan pengurus Partai Demokrat di tingkat pusat dan daerah bahwa Partai Demokrat dinilai gagal. (Ramadhan, 2021)

Pada Penelitian ini peneliti memilih media online sebagai media yang dipilih, banyak media yang memberitakan mengenai Kongres Luar Biasa Partai Demokrat tersebut. Berdasarkan hasil pencarian berita mengenai Kongres Luar Biasa Partai Demokrat pada media online kompas.com yaitu memiliki produksi berita terbanyak dengan jumlah 33 berita dalam 
kurun waktu dua hari dan menurut penelitian, Kompas merupakan media berita online yang memiliki ideologi nasional demokrasi. Hal ini menjadi alasan kenapa peneliti memilih media online kompas.com. (Nasution, 2019)

Kompas.com sebagai bagian dari Kompas Gramedia Group memiliki visi dan misi menjadi perusahaan yang terbesar, terbaik, terpadu dan tersebar di Asia Tenggara melalui usaha berbasis pengetahuan yang menciptakan masyarakat terdidik, tercerahkan, menghargai kebhinekaan dan adil sejahtera. Salah satu alasan peneliti memilih media online Kompas.com karena menurut data dari Alexa.com Kompas.com menduduki peringkat ke 7, Daily pageviews per Visitor Kompas.com mencapai 1.87, Traffic From Search mencapai 53.60\%. Berikut ini adalah peringkat dari media online Kompas.com di Alexa.com.

Media online adalah media komunikasi yang pemanfaatannya menggunakan perangkat internet. Saat ini media online sedang mengalami peningkatan pengguna, banyak masyarakat dari kalangan middle class yang sudah memasuki internet serta media online sebagai salah satu kebutuhan demi menunjang rasa keingintahuan sebuah informasi dari segi apa pun. Media online tergolong media massa yang populer dan bersifat khas. Kekhasan media ini terletak pada keharusan untuk memiliki jaringan teknologi informasi dengan menggunakan perangkat komputer, di samping pengetahuan tentang program komputer untuk mengakses informasi atau berita. (Suryawati, 2016)

Konsep framing oleh Entman digunakan untuk menggambarkan proses seleksi isu dan menonjolkan aspek tertentu dari realitas oleh media. Framing dapat dipandang sebagai penempatan informasi-informasi dalam konteks yang khas sehingga isu tertentu mendapatkan alokasi lebih besar daripada isu yang lain. Framing memberi tekanan lebih pada bagaimana teks komunikasi ditampilkan dan bagian mana yang ditonjolkan atau dianggap penting oleh pembuat teks. (Eriyanto, 2011)

Penelitian ini menggunakan analisis framing Robert N. Entman untuk mengetahui bagaimana realitas di konstruksi dengan pembingkaian. Model Robert N. Entman mempunyai dua dimensi besar yaitu seleksi isu dan penonjolan aspek tertentu. Melalui model ini, peneliti bermaksud ingin mengetahui bagaimana cara pandang yang digunakan oleh media online Kompas.com dalam membingkai berita Kongres Luar Biasa Partai Demokrat periode 5-6 Maret 2021.

\section{METODE}

Menurut Deddy dalam bukunya menjelaskan bahwa paradigma adalah suatu cara pandang untuk memahami kompleksitas dunia nyata. Paradigma tertanam kuat dalam sosialisasi para penganut dan praktisnya. Paradigma menunjukkan pada mereka apa yang penting, absah, dan masuk akal. (Mulyana, 2003) Peneliti menggunakan paradigma konstruktivisme. Alasan peneliti mengambil paradigma tersebut karena berita merupakan hasil dari konstruksi realitas yang bersifat subjektif. Dengan menggunakan paradigma konstruktivisme, peneliti dapat memahami bagaimana peristiwa itu atau realitas dikemas dan dikonstruksikan oleh media berdasarkan sudut pandang Kompas.com.

Peneliti menggunakan Pendekatan kualitatif. Metode penelitian kualitatif ini sering di sebut juga metode penelitian naturalistik karena penelitiannya dilakukan pada kondisi yang alamiah. (Sugiyono, 2014) Pendekatan penelitian yang peneliti gunakan adalah pendekatan kualitatif deskriptif, karena dalam penelitian ini tidak memperoleh metode statistik atau bentuk hitungan lainnya namun lebih menemukan pembingkaian berita yang dibuat Kompas.com tentang Kongres Luar Biasa Partai Demokrat.

Metode penelitian yang digunakan oleh peneliti adalah analisis framing milik Robert M. Entman. Entman melihat framing dalam dua dimensi besar, yaitu seleksi isu dan penekanan 


\section{PROPAGANDA}

atau penonjolan aspek-aspek tertentu dari realitas/isu. Selain dua dimensi besar, Entman juga merumuskan empat elemen framing yakni define problem (pendefinisian masalah), diagnose causes (memperkirakan masalah atau sumber masalah), make moral judgement (membuat keputusan moral), dan treatment recommendation (menekankan penyelesaian) (Eriyanto, 2011).

Framing atau pembingkaian menurut peneliti merupakan sebuah sudut pandang media kepada objek atau tokoh yang sedang ramai di bahas, pada penelitian ini pembingkaian yang di ambil dari media online karena media tersebut merupakan media yang dapat dilihat oleh siapa pun dan kapan pun. Portal berita yang di ambil dari portal berita Kompas.com.

Dalam penelitian ini objeknya adalah teks berita dalam media online mengenai pemberitaan Kudeta Partai Demokrat. Objek yang dipilih oleh Peneliti adalah teks berita pada media online dalam periode waktu 5-6 Maret 2021. Peneliti akan memilih 15 berita dari keseluruhan 33 berita untuk dianalisis karena pada periode tersebut $\mathrm{H}-1$ dan hari di mana adanya Kongres Luar Biasa tersebut. Kemudian judul dan isi ke membahas tentang Kongres Luar Biasa Partai Demokrat.

\section{HASIL DAN PEMBAHASAN}

\section{Hasil}

Penelitian ini akan menjelaskan hasil penelitian tentang pembingkaian berita Kongres Luar Biasa partai Demokrat di media online Kompas.com periode 5-6 Maret 2021. Berdasarkan analisis framing Robert N. Entman yang memiliki dua dimensi besar yaitu seleksi isu dan penonjolan aspek dari suatu realitas dari peristiwa yang terjadi. Oleh karena itu, peneliti membuat hasil penelitian ini dengan sebenar-benarnya dan dijabarkan sesuai dengan teks berita yang telah dimuat oleh Kompas.com dengan menggunakan kerangka pemikiran peneliti buat sebelumnya untuk mengetahui dan menyesuaikan hasil penelitian.

Berdasarkan permasalahan dan tujuan pada penelitian yaitu untuk mengetahui bagaimana Kompas.com dalam membingkai berita terkait Kongres Luar Biasa Partai Demokrat, selanjutnya peneliti akan melihatnya dari segi dua dimensi besar, yaitu seleksi isu dan penonjolan aspek yang sesuai dengan empat tahapan analisis yaitu define problem, diagnose causes, make moral judgment, dan treatment recommendation.

\section{Dua Dimensi Besar Berita Kongres Luar Biasa Partai Demokrat}

\section{Seleksi Isu}

Seleksi Isu Menurut Robert N. Entman, aspek ini berkaitan dengan pemilihan fakta dari realitas yang kompleks dan beragam, kemudian diseleksi aspek mana yang ingin ditampilkan? Di sini wartawan tidak menampilkan semua aspek yang ada, namun memilih aspek tertentu dari suatu isu. Dalam proses ini pasti akan ada aspek yang dimasukkan (included) dan juga aspek yang dikeluarkan (excluded). Tidak semua aspek atau bagian dari isu ditampilkan, wartawan memilih aspek tertentu dari suatu isu. (Eriyanto, 2011)

Pada pemberitaan Kongres Luar Biasa Partai Demokrat, yang dimuat oleh Kompas.com lebih memfokuskan ke isu masalah politik. Hal tersebut dapat dilihat dari seleksi isu yang peneliti jelaskan, dari pemilihan kata judul berita, pembahasan isi berita (terdapat pada lampiran), dan terdapat narasumber yang diwawancara membicarakan masalah pada pemberitaan Kongres Luar Biasa Partai Demokrat.

Agar ada perbaikan kinerja apabila ketua umumnya diganti melalui progres kongres luar biasa.

(Darmizal dalam konferensi pers di Mega Kuningan, Jakarta, Sabtu (27/2/2021), Kompas.tv.) 
Saya bisa menyampaikan ini karena banyak bukti yang kami dapatkan selama ini, pada puncaknya hari ini pada KLB ilegal tadi, maka artinya memang sejak awal motif dan keterlibatan KSP Moeldoko tidak berubah.

(AHY dalam konferensi pers di kantor DPP Partai Demokrat, Jalan Proklamasi 41, Jakarta Pusat, Jumat (5/3/2021))

Saya kira semua tahu dan teman-teman wartawan juga tahu bahwa sejak KLB ini dicetuskan, tokoh pertama yang diusung sebagai ketua umum adalah Moeldoko.

(Max sebelum dimulainya KLB yang diselenggarakan di The Hill Hotel dan Resort

Sibolangit, Kabupaten Deli Serdang, Sumatera Utara, Jumat, Antara.)

Selain itu, peneliti menemukan adanya fakta berita yang dimasukkan (included) dan fakta yang dikeluarkan (excluded) oleh Kompas.com. Fakta berita yang di masukkan (included) oleh Kompas.com adalah dalam pemberitaannya Kompas.com lebih menggunakan kata "Kubu Kontra AHY", lalu fakta berita yang dikeluarkan (excluded) oleh Kompas.com yang sudah peneliti amati adalah media lain lebih spesifik menggunakan kata "Kubu KSP Moeldoko". Adapun fakta yang di masukkan (included) oleh Kompas.com.

Kongres Luar Biasa (KLB) Partai Demokrat yang digelar kubu kontra-Agus Harimurti Yudhoyono (AHY) menetapkan Moeldoko sebagai Ketua Umum Partai Demokrat versi kelompok kontra-AHY. Penetapan itu dilakukan secara aklamasi.

Kemudian peneliti juga menemukan fakta berita lain yang di masukan (included) dan fakta yang dikeluarkan (excluded) oleh Kompas.com. Fakta yang di masukan (included) adalah Kompas.com menampilkan pernyataan dari Marzuki Alie yang menerima terpilihnya sebagai Ketua Dewan Pembina dan akan bergandeng tangan Bersama Moeldoko untuk memenangkan pilpres. Sedangkan fakta berita yang dikeluarkan (excluded) oleh Kompas.com yang berbeda dari media lain yaitu pernyataan Marzuki Alie yang menyatakan dirinya prihatin dengan adanya dualisme di kubu Partai Demokrat. Marzuki Alie dalam pernyataannya sebagai berikut:

Moeldoko Ketum, saya Ketua Dewan Pembina. Jadi keputusan Kongres merupakan keputusan yang tertinggi. Jadi saya dan Pak Moeldoko akan bergandeng tangan untuk memenangkan PD 2024, termasuk memenangkan pilpres.

(Marzuki dikonfirmasi Kompas.com melalui pesan singkat.)

2. Penonjolan Aspek

Aspek ini berkaitan dengan penulisan fakta. Ketika aspek tertentu dari suatu peristiwa atau isu tersebut dipilih, lalu bagaimana aspek itu ditulis? Hal ini sangat berkaitan dengan pemakaian kata, kalimat, gambar dan citra tertentu untuk ditampilkan kepada khalayak. (Eriyanto, 2011)

Penonjolan aspek yang peneliti temukan dari ke-15 berita yang dimuat oleh Kompas.com terkait Kongres Luar Biasa Partai Demokrat, lebih banyak memuat konotasi negatif yang ditampilkan pada artikel berita maupun judul berita.

Penonjolan aspek pada judul berita di Kompas.com sebagai berikut AHY Sebut Moeldoko Ketum Partai Demokrat Abal - Abal Versi KLB Ilegal. Selanjutnya adalah kalimat yang mengandung konotasi negatif terkait Kongres Luar Biasa Partai Demokrat di Kompas.com dalam teks berita.

Selain itu terdapat kalimat konotasi negatif, peneliti juga menemukan penonjolan aspek berupa kata atau kalimat yang sering muncul pada pemberitaan Kongres Luar Biasa partai Demokrat di Kompas.com, kata atau kalimat yang sering muncul sebagai berikut. 
Tabel 2. Penonjolan Aspek Berupa Kata/Kalimat yang Sering Muncul Dalam Pemberitaan Kompas.com

\begin{tabular}{cll}
\hline No. & Kata atau Kalimat & Frekuensi \\
\hline 1 & KLB & 124 \\
2 & Moeldoko & 103 \\
3 & Kader & 50 \\
4 & Ketua Umum Partai Demokrat Agus Harimurti & 14 \\
& Yudhoyono & 17 \\
5 & Kepemimpinan &
\end{tabular}

\section{Framing Robert N. Entman dalam Empat Elemen pada Pemberitaan Kongres Luar Biasa Partai Demokrat pada Kompas.com}

Define problems atau pendefinisian masalah merupakan sebuah cara bagaimana suatu peristiwa atau isu itu dilihat atau sebagai masalah apa. Dalam pendefinisian masalah yang peneliti temukan dalam pemberitaan tentang Kongres Luar Biasa Partai Demokrat, Kompas.com membingkainya dalam masalah politik. Hal tersebut dapat dilihat pada narasumber yang menyebut bahwa ialah bentuk penyalahgunaan kekuasaan dan membicarakan Kongres Luar Biasa Partai Demokrat.

Kepala Badan Komunikasi Strategis DPP Partai Demokrat Herzaky Mahendra Putra menilai, rencana pelaksanaan kongres luar biasa (KLB) yang bertujuan mengambil alih kepemimpinan partai merupakan bentuk penyalahgunaan kekuasaan dari oknum penguasa.

Ketua Umum Partai Demokrat Agus Harimurti Yudhoyono (AHY) mengatakan, sejak awal Kepala Staf Kepresidenan (KSP) Moeldoko memiliki motif yang tidak berubah, yaitu merebut kekuasaan yang sah di tubuh partai tersebut.

Diagnose causes atau memperkirakan masalah atau sumber masalah merupakan sebuah cara bagaimana peristiwa atau isu dilihat disebabkan oleh apa dan siapa yang dianggap sebagai aktor penyebab masalah. Diagnose causes yang peneliti temukan adalah Kompas.com menganggap bahwa kasus ini bermula saat diadakannya KLB Kubu Kontra AHY dan terbukti dihadiri oleh sejumlah mantan kader Partai Demokrat.

Melalui keterangan tertulis yang diterima Kompas.com, Jumat (4/3/2021) ini, Darmizal mengklaim akan melaksanakan KLB dan mengangkat Kepala Staf Kepresidenan (KLB) Moeldoko menjadi Ketua Umum Partai Demokrat yang baru.

Setelah kami cek meminta siapa yang datang tamu-tamu dari luar kota. Maka ditemukan sejumlah nama-nama seperti Jhoni Allen, Nazaruddin, Marzuki Alie, Moeldoko, Darmizal, Ahmad Yahya, Max Sopacua, dll.

(Andi dalam akun Twitternya @ Andiarief_)

Make moral judgement yaitu elemen untuk memberi nilai moral apa yang disajikan untuk menjelaskan masalah. Make moral judgement yang dimuat oleh Kompas.com memberikan penilaian moral yaitu menekankan bahwa KLB yang sah itu diatur dalam AD/ART, kemudian berhubungan dengan rencana pelaksanaan KLB Kubu Kontra AHY untuk mengambil alih kepemimpinan.

Sebab, menurutnya, KLB yang sah diatur dalam Anggaran Dasar dan Anggaran Rumah Tangga (AD/ART) Partai Demokrat yang sudah disahkan di Kementerian Hukum dan HAM berdasarkan Kongres V 2020.

Berdasarkan AD/ART, KLB harus dihadiri dua pertiga dari jumlah pimpinan DPD dan setengah dari DPC dan disetujui majelis tinggi partai. 
Treatment recommendation atau penyelesaian masalah adalah cara penyelesaian apa yang ditawarkan untuk mengatasi masalah peristiwa atau isu tersebut. Pada pemberitaan tentang Kongres Luar Biasa Partai Demokrat, di mana Kompas.com menekankan penyelesaian pada hasil KLB yang akan dibawa ke Kemenkumham. Kemudian AHY menekankan Kembali bahwa dirinya adalah Ketua Umum Partai Demokrat yang sah.

Tentu hasil KLB ini akan dibawa ke Kemenkumham. Saya kira profesionalitas dan independensi Menkumham penting dalam menghadapi situasi ini. Menteri harus netral dalam posisinya sesuai standar hukum yang rigid.

Saya ulangi, saya ulangi, tidak ada dualisme kepemimpinan dan kepengurusan Partai Demokrat. (AHY)

\section{Pembahasan}

Kronologi pemberitaan tersebut bermula saat perebutan kekuasaan Partai Demokrat tersebut, terdapat Gerakan merebut kepemimpinan pada Partai Demokrat dengan adanya Kongres Luar Biasa. Hasil dari KLB yaitu terpilihnya Moeldoko sebagai Ketum Partai Demokrat. Pemberitaan tersebut menimbulkan pemecatan tidak hormat terhadap enam kader partai demokrat. Mereka dipecat karena perbuatannya sendiri yaitu terlibatnya dalam Gerakan pengambilalihan kepemimpinan partai demokrat.

Sebagai media informasi, Kompas.com memiliki fungsi pengawasan dan kontrol sosial yang artinya bahwa media informasi berperan dalam mengontrol informasi mengenai masalah yang berkembang di masyarakat. Terkait dengan Kongres Luar Biasa kubu Moeldoko yang dilaksanakan oleh Moeldoko dan para mantan kader Partai, berbagai spekulasi bermunculan. Media menyajikan informasi sesuai dengan kebijakan redaksinya tersebut.

Melihat dari hasil penelitian yang sudah dilakukan pada Kompas.com periode 5-6 Maret 2021 menggunakan analisis framing Robert N. Entman, maka melihat proses seleksi isu peneliti menemukan bahwa Kompas.com memilih isu politik yang dipublikasikan. Hal tersebut berkaitan dengan fakta pernyataan narasumber yang ditampilkan oleh Kompas.com.

Terdapat alasan mengapa Kompas.com terlihat menampilkan isu politik dibandingkan isu lainnya yaitu narasumber yang diwawancarai adalah sumber berita yang berlatar belakang politik yaitu Agus Harimurti Yudhoyono menjabat sebagai Ketua Umum Partai Demokrat yang menyatakan bahwa adanya Gerakan yang akan mengambil alih kepemimpinan Partai Demokrat, selain itu ada Moeldoko selaku Kepala Staf Kepresidenan yang menerima dirinya dipilih sebagai ketua Umum Partai Demokrat yang baru, kemudian ada Marzuki Alie yang menjabat Sekretaris Jenderal Partai Demokrat dan Darmizal selaku Wakil Ketua Komisi Pengawas Partai Demokrat yang menyebut bahwa sejumlah pendiri dan senior Partai Demokrat merancang rencana KLB Partai Demokrat.

Kemudian isu adanya Gerakan pengambilalihan kepemimpinan pada Kongres Luar Biasa partai Demokrat ini menjadi nyata saat AHY menyampaikan bahwa terbukti KLB itu diselenggarakan di Deli Serdang Sumatra Utara dan Moeldoko yang akan menggantikan posisinya sebagai Ketua Umum Partai Demokrat.

Saya bisa menyampaikan ini karena banyak bukti yang kami dapatkan selama ini, pada puncaknya hari ini pada KLB ilegal tadi, maka artinya memang sejak awal motif dan keterlibatan KSP Moeldoko tidak berubah.

(AHY dalam konferensi pers di kantor DPP Partai Demokrat, Jalan Proklamasi 41, Jakarta

Pusat, Jumat (5/3/2021).)

Dalam penelitian ini, peneliti menemukan fakta berita yang di masukan (included) dan fakta yang dikeluarkan (excluded) oleh Kompas.com. Fakta berita yang dimasukkan (included) 


\section{PROPAGANDA}

oleh Kompas.com dapat dilihat dalam pemberitaannya Kompas.com lebih menggunakan kata "Kubu Kontra AHY", sedangkan fakta berita yang dikeluarkan (excluded) oleh Kompas.com yang berbeda dari media lain adalah media lain lebih menonjolkan kata "Kubu KSP Moeldoko". Berdasarkan penjelasan tersebut, dapat disimpulkan bahwa Kompas.com menganggap KLB itu ialah kegiatan yang dilakukan oleh kubu yang kontra terhadap AHY. Tidak hanya berfokus pada Moeldoko tetapi juga menonjolkan dari pihak yang mendukung gerakan kontra kepemimpinan Ketua Umum Partai Demokrat AHY dan telah diberhentikan secara tidak hormat yaitu Marzuki Alie, Tri Yulianto, Yus Sudarso, Jhoni Allen Marbun, Syofwatillah Mohzaib dan Ahmad yahya dan Darmizal,

Kemudian peneliti juga menemukan fakta berita lain yang dimasukkan (included) dan fakta yang dikeluarkan (excluded) oleh Kompas.com. Fakta yang dimasukkan (included) adalah Kompas.com menampilkan pernyataan dari Marzuki Alie yang menerima terpilihnya sebagai Ketua Dewan Pembina dan akan bergandeng tangan Bersama Moeldoko untuk memenangkan pilpres. Sedangkan fakta yang dikeluarkan (excluded) yaitu pernyataan Marzuki Alie yang menyatakan dirinya prihatin dengan adanya dualisme di kubu Partai Demokrat.

Selain itu, peneliti melihat ada dua isu yang ditampilkan oleh Kompas.com yaitu dari sisi pro dan kontra terkait pemberitaan Kongres Luar Biasa Partai Demokrat. Namun dari narasumber yang ditampilkan lebih dominan pada yang kontra. Dari sisi kontra, narasumber yang ditampilkan yaitu KSP Moeldoko, para mantan kader Partai Demokrat Marzuki Alie dan Darmizal, Politikus Partai Demokrat Max Sopacua. Sedangkan dari sisi pro yang dimuat Kompas.com yaitu memuat pernyataan dari AHY selaku Ketua Umum Partai Demokrat, Herzaky Mahendra Putra sebagai Kepala Badan Komunikasi Strategis Partai Demokrat dan Andi Arief sebagai Ketua Badan Pemenangan Pemilu (Bapipilu) Partai Demokrat.

Pada proses penonjolan aspek, peneliti menemukan penonjolan aspek berupa konotasi negatif yang ditonjolkan pada pemberitaan Kompas.com. Kalimat yang mengandung konotasi negatif terdapat pada judul berita AHY Sebut Moeldoko Ketum Partai Demokrat Abal-Abal Versi KLB Ilegal. Pada judul tersebut, Kompas.com ingin menunjukkan bahwa sejak awal Moeldoko selaku Kepala Staf Kepresidenan memiliki tujuan untuk merebut kekuasaan yang sah pada Partai Demokrat. Lalu hanya AHY yang sah dan diakui pemerintah sebagai Ketua Umum Partai Demokrat keputusan Kementrian Hukum dan HAM.

Kemudian dari isi teks berita yang ditampilkan oleh Kompas.com lebih menonjolkan konotasi negatif atas pemberitaan mengenai Kongres Luar Biasa Partai Demokrat, seperti yang dikatakan oleh Herzaky Mahendra Putra sebagai Kepala Badan Komunikasi Strategis Partai Demokrat bahwa "Berdasarkan penuturan para kader dan pemilik suara sah yang diancam karena menolak hadir. Oknum kekuasaan tersebut bekerja sama dengan mantan-mantan kader yang bergerak atas dorongan insentif money politics, jabatan, dan proyek seperti yang dituturkan para kader yang menolak hadir". Paragraf tersebut menjelaskan Kompas.com ingin menunjukkan bahwa pelaku kekuasaan dan para mantan kader itu melakukan aksinya dengan memperdayakan dan menebar kabar bohong, seolah-olah banyak pemilik suara yang mendukung adanya Kongres Luar Biasa tersebut.

Selain penonjolan aspek berupa makna konotasi negatif, peneliti juga menemukan penonjolan aspek berupa kata/kalimat yang selalu muncul pada artikel berita yang dimuat oleh Kompas.com terkait dengan pemberitaan Kongres Luar Biasa Partai seperti kata KLB yang berarti Kongres Luar Biasa, Moeldoko, AHY, Ketua Umum, Kader, Kepemimpinan.

Penonjolan aspek berupa kata "KLB" merupakan kepanjangan dari "Kongres Luar Biasa" yang muncul sebanyak 124 kali, di mana Kompas.com ingin menegaskan bahwa yang akan bertanggung jawab pada KLB adalah Moeldoko.

Selanjutnya penonjolan aspek berupa kata "Moeldoko" selaku Kepala Staf Kepresidenan yang muncul sebanyak 103 kali, di mana Kompas.com ingin menegaskan dan 
mengingatkan kepada khalayak bahwa yang akan bertanggung jawab pada KLB tersebut adalah Moeldoko.

Selanjutnya penonjolan aspek berupa kata "Ketua Umum Partai Demokrat Agus Harimurti Yudhoyono". Kata Ketua Umum Partai Demokrat yang muncul sebanyak 14 kali, di mana Kompas.com di sini ingin membenarkan dan mengakui AHY sebagai Ketua Umum Partai Demokrat yang sah dan diakui oleh kemenkumham.

Selanjutnya penonjolan aspek berupa kata "Kader" yang muncul sebanyak 50 kali, di sini Kompas.com sering kali menggunakan kata kader yang berarti ingin memberitahu bahwa Kongres Luar Biasa tersebut didukung oleh para mantan kader partai demokrat.

Selain menemukan seleksi isu dan penonjolan aspek, peneliti juga menemukan empat elemen framing yang terdapat pada pemberitaan Kompas.com. yang pertama peneliti temukan adalah define problems atau pendefinisian masalah yang peneliti temukan dalam pemberitaan tentang Kongres Luar Biasa Partai Demokrat, Kompas.com membingkainya dalam masalah politik. Seperti penyalahgunaan kekuasaan yang dilakukan yaitu rencana pelaksanaan KLB kubu kontra AHY bertujuan untuk mengganti kepemimpinan partai Demokrat dan menjadikan Moeldoko sebagai ketua umum Partai Demokrat. Sehingga berdasarkan pernyataan dan narasumber tersebut termasuk ke dalam masalah politik

Yang kedua peneliti juga menemukan diagnose causes atau memperkirakan masalah pada pemberitaan Kongres Luar Biasa Partai Demokrat yang peneliti temukan adalah Kompas.com melihat sumber masalah dalam pemberitaan tersebut yaitu disebabkan oleh adanya Kongres Luar Biasa yang dilakukan Moeldoko dan para mantan kader Partai Demokrat yang mendukung atas Gerakan pengambilalihan kepemimpinan partai yakni Marzuki Alie dan Darmizal. Atas hal tersebut Kompas.com menganggap bahwa Moeldoko sebagai aktor penyebab masalah dalam peristiwa ini.

Yang ketiga peneliti juga menemukan make moral judgement adalah elemen framing yang digunakan untuk memberi nilai moral apa yang disajikan untuk menjelaskan masalah. Dalam hal ini Kompas.com memberikan penilaian moral yaitu menekankan bahwa KLB yang sebenarnya itu diatur sesuai Anggaran Dasar/Anggaran Rumah Tangga, KLB bisa dilakukan apabila sudah disepakati, didukung dan didatangkan oleh 2/3 dari jumlah Dewan Pimpinan Daerah serta juga 1/2 dari jumlah Dewan Pimpinan Cabang.

Yang keempat elemen terakhir yaitu peneliti juga menemukan treatment recommendation atau penyelesaian masalah pada pemberitaan tentang Kongres Luar Biasa Partai Demokrat, di mana Kompas.com menekankan penyelesaian pada hasil KLB yang akan dibawa ke Kemenkumham. Dilaksanakannya KLB juga harus disetujui oleh Susilo Bambang Yudhoyono sebagai Ketua majelis Tinggi Partai.

\section{PENUTUP}

Berdasarkan dari hasil penelitian dan pembahasan yang bertujuan untuk mengetahui frame berita Kompas.com pada pemberitaan Kongres Luar Biasa Partai Demokrat. Peneliti menggunakan analisis framing Robert N. Entman untuk menganalisis teks berita KLB Kubu Moeldoko yang dilakukan di Deli Serdang Sumatra. Dari hasil yang sudah dijabarkan bahwa frame Kompas.com menempatkan pemberitaan Kongres Luar Biasa Partai Demokrat merupakan masalah politik. Moeldoko ditempatkan sebagai aktor penyebab masalah yang sudah menyebabkan kehebohan publik. Namun setelah dilihat dari pemilihan narasumber yang dimuat oleh Kompas.com dan pernyataan yang dikeluarkan, dan juga penonjolan aspek yang ditonjolkan, Kompas.com lebih memperlihatkan pada isu politik dari kasus pemberitaan KLB Partai Demokrat dengan menampilkan narasumber yang berlatar belakang politik yaitu Agus Harimurti Yudhoyono sebagai Ketua Umum Partai, selain itu ada Moeldoko selaku Kepala 


\section{PROPAGANDA}

Staf Kepresidenan, kemudian ada Marzuki Alie yang menjabat sebagai Sekretaris Jenderal Partai Demokrat dan Darmizal selaku Wakil Ketua Komisi Pengawas Partai Demokrat. Hal tersebut bisa dilihat dari penonjolan aspek berupa kata yang menegaskan keberpihakan Kompas.com pada AHY. Dalam pemberitaannya Kompa.com sering kali menggunakan kata seperti "KLB", sering juga menyebutkan nama "Moeldoko" yang berarti bahwa Kompas.com ingin menegaskan bahwa yang akan bertanggung jawab atas KLB adalah Moeldoko, Kompas.com ingin menyatakan juga yang jelas bersalah atas peristiwa ini adalah Moeldoko. Terdapat kalimat yang sering digunakan yaitu "Ketua Umum Partai Demokrat Agus Harimurti Yudhoyono" yang berarti bahwa Kompas.com di sini ingin memastikan pada khalayak bahwa ketua umum yang sah adalah AHY.

\section{DAFTAR PUSTAKA}

Eriyanto. (2011). Analisis Framing - Konstruksi, Ideologi, dan Politik Media. Yogyakarta: LKiS.

Mulyana, D. (2003). Metodologi Penelitian Kualitatif. Bandung: PT. Remaja Rosadakarya

Ramadhan, A. (2021). Penunjukan Moeldoko jadi ketum demokrasi versi KLB dinilai anomaly politik dan demokrasi. https://nasional.kompas.com/read/2021/03/06/14215641/penunjukan-moeldoko-jadiketum-demokrat-versi-klb-dinilai-anomali-politik

Ramadhan, A. (2021). Isu kudeta di emokrat yang berujung pemecatan 7 kader. https://nasional.kompas.com/read/2021/03/01/07453731/isu-kudeta-di-demokratyang-berujung-pemecatan-7-kader?page=all

Sugiyono. (2014). Metode Penelitian Pendidikan Pendekatan Kuantitatif, Kualitatif dan R\&D. Bandung: Alfabeta.

Suryawati, Indah. (2011). Jurnalistik Suatu Pengantar Teori dan Praktik. Bogor: Ghalia Indah. https://www.alexa.com/topsites

https://www.kompasgramedia.com/about-kg/vision-mission

https://nasional.kompas.com/read/2021/03/05/12044501/demokrat-rencana-klb-jadi-buktipenyalahgunaan-kekuasaan?page $=$ all

https://nasional.kompas.com/read/2021/03/05/08481361/kubu-kontra-ahy-klaim-gelar-klbdemokrat-hari-ini?page $=$ all

https://nasional.kompas.com/read/2021/03/05/20321731/ahy-sebut-sejak-awal-motifmoeldoko-tidak-berubah?page=all 